\title{
Comunitarian of Fisherman, Fisheries and Local Government Communities, Management of Results of Coastal Resources in Riau Province
}

\author{
Geovani Meiwanda ${ }^{1}$, Pandhu Yuanjaya $^{2}$, Dadang Mashur ${ }^{3}$, Adianto $^{4}$ \\ ${ }^{1,4}$ Universitas Riau, Indonesia \\ ${ }^{2,3}$ Universitas Negeri Yogyakarta, Indonesia \\ 1'geovani.meiwanda@lecturer.unri.ac.id, 2pandhu@uny.ac.id, 3da2nk_mashur@yahoo.com, \\ 4adianto@lecturer.unri.ac.id
}

\begin{abstract}
Communities are part of social groups. fishing communities are supporters in creating prosperity for coastal communities in Rupat Utara. The purpose of the study is how can the Communitarians in North Rupat be sustainable, so that they are able to support the welfare of fishermen in Rupat Utara. Rupat north directly faces the Straits of Malacca, international waters become an interesting study. Each fisherman joins and chooses not to join, but both do not provide welfare. This research uses the concept of communitarian Etzioni, this concept reflect that a community based can be increase and connector between government and public. using qualitative research methods involving village officials, Bengkalis district government representatives and fishermen who are grouped or not. The results showed that the community was formed in a limited function, has a structure and culture but was not able to facilitate the needs of fishermen, in an effort to prosper the coastal community. Fishing communities do not have welfare, although almost every village forms its community. assistance and assistance that had been provided by the Bengkalis district government was deemed not on target, as needed. the gap between coastal fishermen also occurs between Rupat Island and Bengkalis Island.
\end{abstract}

Keywords : Communitarian, Coastal Area, Coastal Communities, Welfare.

\section{Introduction}

Coastal areas in Indonesia have the same problem, which has the status of poor households based on Statistics of Marine and Aquatic Resources by BPS 2018. Riau Province is geographically located adjacent to neighboring countries, one of which is the coastal area of Riau located in Bengkalis Regency namely Rupat Island in parts north, directly bordering the Strait of Malacca. Coastal communities are synonymous with communities that have a limited mindset and also low levels of education, communitarians are always formed from social and cultural construction (Schmitt, 2016). The situation of coastal communities requires proper policies from the government, and this article explains that a community or group should be able to contribute in producing good policies for fishermen.

Coastal Gate is one of the focuses of development zoning in Bengkalis Regency. Rupat Island is a part of Bengkalis Regency which is a coastal zone in the north which directly faces Malacca Strait. The North Rupat Coastal Area needs special attention from the Local Government. The coastal region is an area rich in marine potential, and its natural beauty. The potential that has so far needed to be a major intervention between the community itself, the 
government and third parties. The fisheries sector is a very big thing there but does not have great value for the community.

Fisheries resources from Rupat coastal marine products are assets for the community and fishing communities. Optimal management requires a sustainable development approach. Central and regional governments are required to be agile in making and implementing policies for coastal areas, so that they are in accordance with the condition of marine fisheries resources.

There was a change in the conception of society, towards a model of liberalism that prioritizes aspects of competition, liberalization, and the element of participation. These three elements gave birth to a paradigm of individuality which became the main orientation. Individuality becomes a logical consequence of public policy that puts forward the elements of liberal democracy. The pattern of community life that is developing at this time, through a democratic system of society can be realized in 2 main levels; procedural (structural), and cultural. Procedures related to determining public policy, the process of determining leadership, and actualization of community interests. Culturally, the point of view is very much influenced by the culture of the local people. The multicultural condition of society also fills the community in the North Rupat region, becoming a capital in the application of cultural types of democracy.

The weakening of the strength and objective function of the community in managing local resources on the northern part of Rupat Island has caused some significant impacts on the community's economy significantly. The community knows that the potential of deep-sea fisheries that are very close to them, does not have maximum value. The tendency of local resources owned and obtained by the community currently has a very low sale value, not in accordance with market prices. The situation is inversely proportional to the existence of Rupat Island as an area that has the potential for tourism development.

Eight villages are administrative regions of the North Rupat District, with TanjungMedang Village being the capital of the North Rupat District. TanjungMedang, which is the center of the Subdistrict, a small port for access in and out is also found in the village of TanjungMedang and where fish collectors from fishermen along the coast of North Rupat are also located in the village of TanjungMedang. The profession of the local community is almost on average a profession as a fisherman, fishermen are also considered as a profession that is hereditary. Of a number of villages in the North Rupat Subdistrict, only two villages do not have coastal, coastal and sea areas.

TanjungPunak Village and TelukRhu Village are one of the villages where the community has managed and become fishermen since they went downhill, and in the past often carried out trading transactions to foreign ships that crossed. The number of fishery households in TelukRhu Village is 321 fishing households (RTP). Coastal areas Besides this, North Rupat Fishermen receive serious attention from the central government and from the regional government, in terms of the welfare of fishermen, it is also not free from saving the environment and various fishing gear and facilities.

Circumstances and the economy are not separated also become a problem for the local community, this situation will be aggravated again by the existence of poor people. To merely defend their lives, the poor are often forced to exploit natural resources, both in their control and common property, which results in the degradation of natural resources and the environment. 


\section{Methodology}

\subsection{Komunitarian}

The view of the welfare of a country has power, but it must maintain that power. The state must divide tasks among individuals, families and communities. Apply the principle of subsidiary. Communitarians emphasize that responsibility for each situation first falls to those closest to the problem. Only when the solution cannot be found by individuals, then the family must be involved. If the family cannot overcome it, then the local community can get involved. If indeed the problem is too big for the community, then the state is allowed to be involved (Parsons 2005).

Communitarism proposes some critical notes on the views of liberals (Anzenbacher, 2012), some important points of criticism from the communitarians are:

a) Communitarians reject the concept of liberal anthropology which sees humans as unencumbered self 'or humans without community. Communitarians in point of view, humans side by side with communities, traditions and social ties.

b) Communitarians provide solutions to the problems of individualization, economization and decentralization. By strengthening groups with practice and internalization of cultural identity, social ethos, solidarity and togetherness tied back. The process of integration into communities and communitarian traditions.

Gerry van Klinken mentions the emergence of communitarian politics in the context of post-Soeharto regional autonomy and decentralization, but his observations were limited to the revival of local courts. Vedi Hadiz and Robert Hefner, linking some of Indonesia's political ideas and actions with communitarianism as debated in philosophy and political theory, although their initial analysis departs from discussions on the contrast between Western democracy and 'Asian values' based democracy - cynically it is often called' illiberal democracy'

Rousseau in (Anzenbacher, 2012) that the government must guarantee the implementation of individual freedom in society. According to Taylor in (Anzenbacher, 2012), the value of liberal individualism is atomistic, which considers individuals to be sufficient for themselves outside of society. Individuals according to liberalism do not need a community context to develop and carry out their capacity to determine themselves. According to Taylor, an individual's capacity to determine and develop himself can only be carried out only in the context of a particular community, with a certain social environment.

Michael Sandel was the first figure to open a debate around Communitarianism with Liberalism around 1982 through his work entitled Liberalism and The Limits of Justice. This work by Michael Sandel is a criticism of John Rawls's hypothetical thinking. The Rawls Thesis stresses that society is good if the conditions of society are fair. For the condition of society to be fair, the order that governs people's lives must contain two principles, namely the principle of equality and difference which is carried out based on the principle of lexical priority (Kymlicka, 2004 :). First, the principle of equality; each person has the same right to the whole broadest system of the same basic freedoms according to the same freedoms for everyone. The first priority rule (priority of freedom) is that the principles of justice are arranged in a lexical order and therefore freedom can only be limited for the sake of freedom itself. Second, the principle of difference; social and economic inequality are arranged so that both: (a) provide the greatest benefits for the most disadvantaged, and (b) open positions and positions for all under conditions of equal opportunity. The second priority rule is the priority of justice for efficiency and prosperity. The second principle of justice is lexically more 
important than the principle of efficiency and the principle of maximizing the total amount of benefits and opportunities that is more important than the principle of difference.

\section{Research Method}

Qualitative methods are considered to be able to answer the purpose of this article. The case study taken is the North Rupat coastline in villages directly facing the beach, and also directly in the area of the North Rupat District administration. In order to obtain accurate data, accurate, fast, efficient, and economical data collection techniques are also needed, as follows: (a) Interview, which is the technique of extracting data and information in more depth, in an effort to comprehend comprehensively by means of direct question and answer addressed verbally to respondents, which contained a number of conceptually appropriate main questions in the focus of this article, with the aim of making it easier for researchers to conduct interviews, because the questions have been structured so that they get results that are as expected. Interviews were conducted involving government stakeholders in UPT Bengkalis Regency, Rupat Utara District, TanjungMedang Village Officials, TelukRhu Village Officials, TanjungPunak Apparatus, Fishermen and Fishermen Groups who were not included in the group (b) Observation, which is a technique to get data from where the research activity was observed.

This article provides a communitarian presentation in a number of coastal fishermen groups in the North Rupat District, and provides benefits for the welfare and sustainability of the fishing groups. From the existing conditions in the region shows that, each region has a coastal coast and get income from marine products. With the data analysis method used data triangulation, the data that has been selected then the data collected and then reduced and then analyzed, resulting in data analysis.

\section{Result and Discussion}

The Return of Tradition: Rationality and Ethical Communitarian Alasdair Macintyre, Amin Mudzakkir in the Indonesian Institute of Sciences - LIPI ISSN 2407-0556. MacIntyre specifically refers to Ancient Greece and the Middle Ages as formulated by Aristotle and Thomas Aquinas who integrate ethics and politics into everyday social practice, but it does not rule out the possibility that these examples cannot be applied in Indonesia in modern times.

Liberalism and Communitarianism: Concepts of Individuals and Communities, differences in liberalism and communitarianism which have different points of view in placing individuals and communities. Liberalism focuses attention on individual autonomy, but that does not mean negating the community. Focused on being a member of the community, and the community can not reduce the existence and freedom of individuals who are members. On the other hand, communitarianism focuses attention on the community which is the context of individual existence, but that does not mean ignoring the existence of the individual itself. Individuals are precisely considered to be autonomous and have freedom and equality in accordance with the values of liberalism if the community is also autonomous. Therefore, the two streams in political philosophy are different but not necessarily opposeionally. A certain unjust community habit then this criticism should not be done outside of that community. But the person must enter the community, then submit other interpretations that are considered 
better / fair. In short, the truth will be obtained from what is shared. Therefore to be able to define what is fair must refer to a particular community. Even if there will be differences of opinion in the community then it must be returned to the shared understanding of the community concerned so that potential conflicts can be prevented.

The Relevance of Utilitarianism, Liberalism, Libertalianism, and Communitarianism in Islam, in Ishak Hariyanto Communique, Volume 7, No. 1, June 2015 Opening the horizon of our knowledge more broadly, so that we are more tolerant and wise in dealing with the phenomenon of social social phenomena. North Rupat district has a great potential that is obtained from Indonesia's natural wealth, namely the fisheries sector captured from the sea. Geographically North Rupat is dealing directly with the Malacca Strait, of course Riau's outermost border region which is very strategic if it is able to be well developed. The fishing profession is a thing that has been carried down from generation to generation, currently more and more studies are investigating that coastal communities are less developed and continue to be in marginal conditions (Satria, 2015).

Rupat Utara as a coastal area that is in the outermost region, because it is in the international waters region does not contribute to building community welfare. Fishermen and sea products automatically become part of every community in the Riau coastal region. As has been explained in the background, almost the same thing happens in other places, people do not have a high level of education and economic growth is not developing (Meiwanda, G., Meilani, N. L., \& Amri, 2019). Higher education levels only complete basic education, then choose to become a fisherman because it is considered work that for generations must definitely be done, with minimal limitations

A number of people in addition to their profession as fishermen, also gardening with small capacity. The sale of fish does not provide change and growth for the community, the assistance obtained through the group is considered not on target also being argued by a number of fishermen in the area. Fishermen form groups as a form of demand from the state, for fishermen who get help. Existing groups must have legality, so they can be eligible for assistance and assistance. Traditionally that communitarians will strengthen the value of groups traditionally and can minimize social problems (MacIntyre, 1980), communitarian fishermen do not run with the actual meaning that can not be separated because the basic understanding of fishing groups is formed.

Each village has its own fishing group, and almost all of the fishing communities do not implement the communitarian concept described by Etzioni in the journal (Schumaker, 2018), a good community is a homogeneous community that is able to accommodate the needs of each member, but has connections long-term benefits for the community and members of the fishing group. Illustration of the concept can be stated in the maping model (Meiwanda, G., Meilani, N. L., \& Amri, 2019).

Looking at the presence of the State for the welfare of coastal communities, most of whom work as fishermen are still considered to be very minimal. It is understood that the State or the government is helping in welfare efforts in the form of simultaneous assistance or assistance and training. The training program that was given to them was implemented but did not have a big effect, because the fishermen did not think that was what they needed (Purnama et al., 2016). The work that is considered as hereditary work, so the approach in providing socialization must also be able to read the characters of the fishermen in the North Rupat District. This proved to be very good physical assistance, but it did not provide benefits because of the limitations possessed by fishermen who were previously unable to be answered. Fishermen groups can not make themselves as a liaison and communicator between fishermen and the government, communitarians must certainly be profitable because it cannot 
be separated from the doctrine provided to produce positive welfare efforts obtained by group members (Rawls, 2005).

The fishing communities in Rupat Utara District are only formed to meet the needs of fishermen when making requests for assistance. If the goals achieved in just one goal certainly will not provide sustainability, the field facts show that not all fishermen feel that joining the group will be profitable because in the end they will sell to a number of tokens individually. The sign cards of fishermen and fishermen groups, the essence when joining a fishing group provides benefits in the form of profit sharing and the group seeks welfare for the community of fishing communities.

Fishermen and Fishermen Groups are not able to provide their own strength, in presenting the welfare of the income derived from the sea. The price of fishermen's catch depends on the value of the Ringgit currency. Low fish prices, supported by a monopoly on the sale of fish products strengthen the situation of the weak economic value of marine products. The threat to coastal fishermen is so great because of the geographical location of the North Rupat Region.

There is no synergy between the government and the fishing community and the fishermen can be seen from the fact that there is no maximum attendance of assisting fishermen groups. Commitment to participatory democracy patterns that involve governance structures is also needed in the process (Barkin\& Sánchez, 2019). The involvement of local actors from the group and the local government as well as support from the fishermen assisting entrepreneurs, are not able to balance and try to minimize degradation, because the fishermen themselves are confused by the parenting patterns of the fishing groups. Some fishermen prefer not to join the group, because they do not feel any benefit from the group. The strength of private actors that are so thick cannot be accommodated by groups of fishermen, so every fisherman relies on private actors in this case are fish collectors. The needs of fishermen and catches that depend, to fish collectors, show groups of fishermen exist but do not give a position as communitarians.

Substantial of the presence of the communitarian function, then emphasizing the need for multidisciplinary science, in the communitarian revolution itself, especially what happened in the fishing community. Communitarians through fishing communities become subordinates which ultimately do not show economic value advantages plus the government cannot capture the dynamic and plural of coastal communities, thus assuming that the state is not present. The social actors of the fishing community did not attend to complete the communitarian function that existed in a number of fishing groups, so that it became massive. Impact factors are social actors that are less power so that there is no welfare value generated from the community. The capitalist coastal area which became a superior place was dependent on a number of fishermen.

Theoretically, the communitarian function becomes a subsidiary that will become a bridge to connect fishermen and the government. Minimize the poverty space of coastal fishermen in Rupat Utara. But the reality of the inability of social actors from communitarians in North Rupat, in this case represented by the head of the group becomes the situation of fishermen becoming subordinate which is not favorable. The existing group in the North Rupat coastal area of Riau Province has a large quantity, but does not provide communitarian contributions in practice.

The limited economic, social and political knowledge of the communitarians results in the inability of the fishermen and their communities to manage the potential of their territories so that the impulse to the state is reasonable in this case the government does not arrive. Likewise the government is unable to read the problematic dynamics of small organizations through groups, which have been at the center of capitalists. A problematic situation which is exploited 
by a number of collectors' places, monopolizing the fish caught by fishermen. The boundary region always presents uniqueness and challenges, so as if it shows that Coastal Rupat Fishermen, Indonesia is like a satellite country that relies on the economic value of fishermen on Malaysia.

\section{Conclusion}

Communitarian coastal communities in Riau Province are not able to produce three things that are the substance of achievement of the three main things namely tradition and social contracts that benefit fishermen, the principle of equality and the principle of difference, which dominates only on equality because it requires help not making changes, situational Communitarian fishing communities in their groups, do not produce structures and culture that will later contribute to producing policies with a bottom up pattern, in accordance with the subsidiary system in communitarians. The gap that emerges from below, between the government and the fishermen groups, which makes the government and fishermen groups' situations are not synergized.

\section{References}

[1] Afrizal., 2016., Metode Penelitian Kuantitatif.,Raja Grafindo Persada., Jakarta.

[2] Aida, Ridha. 2005. Liberalisme dan Komunitarianisme: Konsep tentang Individu dan Komunitas. DEMOKRASI Vol. IV No. 2.

[3] Amin Mudzakkir, ... Kembalinya Tradisi: Rasionalitas Dan Etika Komunitarian Alasdair Macintyre. Lembaga Ilmu Pengetahuan Indonesia - LIPI ISSN 2407-0556

[4] Amrizal, Safrizal, Mahdi dan Junaidi, 2016. Pengembangan Usaha Perikanan Laut Berkelanjutan Berbasis Zona Penangkapan di Kabupaten Bengkalis, Disertasi Program Doktor Pascasarjana Universitas Andalas, Padang (tidak dipublikasikan)

[5] Badrudin, N.N Wiadnyana, B.Wibowo, 2005. Deep water exploratory bottom long lining In the waters of the Arafura Sea. Indonesian Fisheries Research journal, 11 (1) : pp 41-46.

[6] Badrudin, Wudianto, N.N. Wiadnyana, dan S.Nurhakim, 2006. Deep sea fish resources Diversity and potential in the waters of western Sumatera of the Eastern Indian Ocean.Indonesian FisheriesReseach journal. 12(2) : pp 113-12.

[7] Bailey andBrorsen (1989). Price Asymetry in Spatial Fee Cattle Markets.Western Journal of Agriculture Economics, Vol. 14. pp 246-252 .

[8] Brill, R.W.et al, 1999. Horizontal Movements and depth Distribution of large adult Yellowfin tuna (Thunnus albacores) near the Hawaiian Islands, recorded using Ultrasonic telematry: Implications for the physiological ecology of pelagic fishes, Marine Biologi (133) pp $395-408$, Hawaii.

[8] Dahuri, R., 2001. Potensi dan permasalahan pembangunan kawasan pesisir Indonesia, Pusat kajian sumber daya pesisir dan lautan IPB, Bogor.

[9] Fauzi, A.dan S.Anna, 2005. Permodelan sumber daya perikanan dan kelautan untuk analisis kebijakan, Gramedia pustaka utama, Jakarta.

[10] Ghofur, Abd. 2014. Problematika Pembangunan PulauTerluar dan Pemberdayaan Masyarakat di Kecamatan Rupat Utara Kabupaten Bengkalis. Jurnal Toleransi: Media Komunikasi Umat Beragama, 6 (1).

[11] Hariyanto, Ishak. 2015. Relevansi Aliran Utilitarianisme, Liberalisme, Libertalianisme, Dan Komunitarianisme Dalam Islam. Volume 7, No. 1, Juni 2015

[12] Indiahono, Dwianto., 2009.,Perbandingan Administrasi Publik., Gava Media., Yogyakarta. 
[13] Kusumanegara, Solahuddin., 2010.,Model dan Aktordalam Proses Kebijakan Publik.,Gava Media., Yogyakarta.

[14] Nugroho, Riant., 2006.,KebijakanPublikuntuk Negara-Negara Berkembang., PT. Elex Media Komputindo., Jakarta.

[15] O tto G usti M adung, 2012. Relevansi perdebatan liberalism versu komunitarisme untuk konteks Indonesia. $634 \mathrm{M}$ illah Vol. XI, No. 2, Februari 2012

[16] Sartika, Ika. 2011. Evaluasi Kebijakan Pemberdayaan Nelayan. Jurnal Ilmu Administrasi Negara, 11 (2).

[17] Parsons, Wayne., 2005.,Public Policy PengantarTeori dan Praktik Analisis Kebijakan., Kencana., Jakarta.

[18] Tonny, Judiantono. 2011. Analisis Pola dan Estimasi Pergerakan Barang Sebagai Pertimbangan prioritas Pembangunan Jalan di Kabupaten Bengkalis - Provinsi Riau. Jurnal Perencanaan Wilayah Kota Universitas Islam Bandung, 2 (11).

[19] Anzenbacher, A. (2012). Ethik: Eine Einführung. German: Patmos-Verlag.

[20] Barkin, D., \& Sánchez, A. (2019). The communitarian revolutionary subject: new forms of social $\begin{array}{llll}\text { transformation. } \quad \text { Third } & \text { Wuarterly, } & \text { 1-23. }\end{array}$ https://doi.org/10.1080/01436597.2019.1636370

[21] MacIntyre, A. (1980). After Virtue. Notre Dame: University of Notre Dame Press.

[22] Meiwanda, G., Meilani, N. L., \& Amri, K. (2019). Komunitarian Masyarakat Nelayan Indonesia: Kawasan Pesisir Rupat Utara. Jurnal Kebijakan Publik, 10(2), 83-90.

[23] Purnama, C. R. A., Besar, B., Pelayanan, P., Jl, S. B., Sosial, K., \& Sonosewu, N. (2016). Analisis Kebutuhan Pelayanan Sosial bagi Keluarga Nelayan Miskin. (1), 219-234.

[24] Rawls, J. (2005). Political Liberalism (expanded ed). New York: Columbia University Press.

[25] Satria, A. (2015). Pengantar Sosiologi Masyarakat Pesisir. Buku Obor.

[26] Schmitt, O. (2016). Meanings of Community across Medieval Eurasia. Meanings of Community across Medieval Eurasia. https://doi.org/10.1163/9789004315693

[27] Schumaker, P. (2018). Amitai Etzioni: Communitarian Centrist and Principled Pluralist. Social Science Journal, 55(1), 4-5. https://doi.org/10.1016/j.soscij.2018.02.004 